\title{
Miguel Reale, Humanista
}

\author{
Miguel Reale Gúnior
}

Aos noventa anos de meu pai, várias manifestações de regozijo estão se realizando, para saudar a oportunidade, favorecida pelo dest no, de permitir que com tão avançada idade tenha o nonagenário a mais íntegra capacidade de produzir trabalhos, nos quais agora se misturam a vasta cultura acumulada com a sabedoria, que ele mesmo define como equilíbrio e justa medida ${ }^{1}$. Estes não se confundem com o bom senso, que pode ser ocasional, enquanto a sabedoria é marcada pela constância e retidão.

Outra característica da sabedoria está em não se fechar o sábio no seu casulo, bastandose a si próprio e indiferente ao mundo dos demais mortais. O sábio deve ser, diz REALE, um participante e o sentido da partici pação criadora lhe é inerente.

É justamente esta partici pação criadora que REALE tem manifestado ao transmitir os frutos de sua sabedoria por meio dos artigos que quinzenalmente publica no jornal "O Estado de São Paulo". Reunidos na coletânea "Variações", a primeira constatação que se faz está no variado das "variações", na multi plicidade de vertentes do espirito humano que são abordadas.

Tive oportunidade, em meu discurso de posse como professor titular da Faculdade de Direito da USP, de dizer que era um homem de sorte, primeiramente por ter nascido filho de

Variações, Sẫo Paulo, Edições GRD, 2000, 2"a
MIGUEL REALE. Passados 12 anos daquela oportunidade, repito o que disse, sou mesmo um homem de sorte, pois a convivência diária com meu-pai, em casa e no escritório, tem revelado sempre um homem em contínuo processo de ensinamento, antes de tudo suscitando valores, conduzindo de um ponto a outro fixado como meta, numa interelação educador-filho ou aluno de caráter concreto e afetivo, uma transmissão de vivências que não se limita a uma fria informação de conhecimentos.

Diz REALE, então, que a educação tem por fim primordial a formação e a realização da personalidade, $e$ foi isto que vivenciei e vivencio ao seu lado, como filho, aluno, leitor e colega de escritório. Creio que nos artigos já mencionados, reunidos sob o título "Variações", o processo educacional e a partici pação criadora inerente ao sábio se fazem mais presentes, e pretendo, neste trabalho, destacar algumas das idéias mestras que iluminam a tarefa jornalística do homenageado.

Primeiramente, foi para mim sempre sedutora a compreensão unitária do homem e de suas formas de manifestação sob a égide de uma constante afirmação de valores, que se revelam ao longo da história e que passam a integrar, inafastavelmente, o seu patrimônio cultural.

É esta uma das idéias básicas a que repetidamente REALE recorre, e essencial em seu pensamento. Interessa não o homem abstrato, p. 169. 
visto como entidade ideal, mas sim o homem concreto, situado em seu tempo e contornado por suas circunstâncias, como expressa ORTEGA Y GASSET. A primeira vista afirmar-se-ia um relativismo histórico, que inviabilizaria o reconhecimento de direitos humanos fundamentais.

Superando esta dificuldade, sem cair no jusnaturalismo, teológico ou racional, conform se ancore em Deus ou na razão a revelação ao homem dos valores positivos e do justo, REALE indica a existência de invariantes axiológicas, que define como valores supremos e universais, tais como o da pessoa humana, da liberdade da solidariedade, "que se projetam do processo histórico, pairando acima dele como se fossem inatos. $\mathrm{Na}$ realidade, emergem, a meu ver, $\mathrm{d}$ história mesma, nela adquirindo sentido e força transcendentais por corresponderem à misteriosa unidade da natureza humana ${ }^{2 "}$.

Inserido na história, o homem concreto é espelho de seu tempo, de tal forma que, conforme REALE, é impossível separar o sentido auroral da música de $\mathrm{BACH}$ do despertar da era iluminista, tal como CHOPIN prende-se à vaga romântica ${ }^{3}$, mas nem por isso a experiência histórica deixa de consagrar valores que se incrustam no modo de ser do homem, forman do a sua "natureza", valores que "deixam de ser considerados bens transitórios para se firmarem como permanentes e intocáveis", sem que cons tituam uma verdade absoluta revelada de antemão.

Desse modo, a multifária e complexa experiência histórica, na qual o homem expõe suas grandezas e fraquezas, termina por otimisticamente incorporar valores positivos, que se transformam na forma indissolúvel de ser do homem, em uma árdua conquista de marcos

definitivos da cultura. Assim, do homem concreto, em sua experiência nos planos mais diversos, da política, da economia, da arte, da religião, do amor alça-se vôo às invariantes axiológicas, que parecem inatas mas não o são, pois significam revelações proporcionadas pela própria história, constituindo-se, à semelhança do formulado por MAIHOFER, um direito natural concreto, historicamnete condicionado.

E a mais fundamental das invariantes axiológicas é a pessoa humana, "raiz legitimadora dos direitos humanos", valor-fonte de todos os valores ${ }^{4}$

Como resultado imediato da pessoa humana como valor-fonte, vários outros valores revelam-se, também, como fundamentais e igualmente experenciados no processo histórico, tais como a liberdade e a justiça. Assim, segundo REALE, desde as revoluções políticas e iluministas do fim do século XVIII não pode mais o homem viver sem as liberdades fundamentais, que compreendem as liberdades política, religiosa, artística, econômica, bem como a liberdade do trabalho e do ócio.

Ressalte-se que REALE jamais se despreende do real, infenso a uma concepção ideal da pessoa humana, sempre situando-a na experiência da vida cotidiana, de tal modo que a liberdade ele só a compreende como manifestação que se põe na "concretude de um ser espiritual partici pante capaz de criar algo novo e valioso para si e para a sociedade em que vive".

Outra idéia força, que amarra o homem ao seu destino concreto, é a de que o ser do homem é o seu dever ser ${ }^{5}$, transcorrendo a existência entre o experenciado e o experenciável, pois cada ser humano realiza-se em função de um projeto adequado às suas inclinações e potencialidades.

Assim, o homem é forçosamente a história de si mesmo, vive no tempo, sempre se projetando ao futuro, mas a partir do arsenal do já experenciado, ou seja, é enquanto deve ser. Não é apenas memória, nem tão só futuro, mas um amálgama, pois é próprio da condição humana recolher a experiência passada, mas sempre ter o impulso para o desenvolvimento de novas tarefas. Isto é verdadeiro, também, para o velho, para quem, como diz REALE, importa memória do tempo ${ }^{6}$, da qual, todavia, "emerge uma intuição criadora ou renovadora para compensar as naturais debilidades da velhice, reabrindo de par em par a porta da esperança".

E é na temática do tempo que mais angustiosamente se debruça o homenageado. Voltado a edificar a grandeza do homem con creto, em suas vivências sensitivas na experiência cotidiana, com os olhos sobre este homem particular, inserto na história e propulsionador da história, REALE preocupa-se de como é e como deve ser vivido o tempo.

Importante a distinção que estabelec entre tempo quantitativo e tempo qualitativo. primeiro próprio da praxe, o segundo concreto e existencial, impossível de ser medido pelos ponteiros do relógio.

O tempo é diversamente sentido, passa depressa ou vagarosamente conforme o que se vive. Diz CAMUS que o dia no escritório passa rápido, e tem razão, mormente comparando-o com o tempo do ócio forçado do desemprego. Lembra REALE a relação feita por UGO SPIRITO entre tempo e preocupação. E se cabe razão a ORTEGA Y GASSET, há homens ocu-

${ }^{5}$ Variaçóes, cit. p. 27 e 83.

${ }^{6}$ Variaçōes, cit. p. 45.

Variaçôes, cit. p. 35.

${ }^{8}$ Variaçöes, cit. p. 131. pados e homens preocupados, sendo a meu ver mais longo o tempo vivido na preocupação do que o gasto na ocupação.

O tempo é diferentemente sentido, exemplificando REALE, que é alegre o tempo das intuiçōes criadoras ${ }^{7}$, pianíssimo o do ensimesmamento, doce e dolente o da saudade. Diversos são os tempos da raiva, da paixão, ou do terror em um assalto de poucos minutos que à vítima parece uma "eternidade". Outro é o tempo, também, como lembra RICARDO ANDREUCCI, vivido em um presídio onde, desfeito o condenado dos papéis sociais que representava, espera ansioso o julgamento de um recurso que lhe poderá devolver a liberdade perdida.

Posso dizer que no campo, com a harmonia dos elementos da natureza a entrar pelos olhos, as horas têm sessenta minutos, enquanto na turbulência sôfrega de São Paulo as horas possuem trinta e cinco minutos.

Certa feita, na fazenda, montando égua de nome Brasília, pertencente a um empregado, reclamei da lerdeza do animal, ao que o caboclo retrucou:"andá ela anda, a gente é que precisa aprender a andá na paciência dela". É o tempo existencial, um na roça, outro na grande cidade.

O amor também apresenta tempos diversos, e o amor matrimonial, segundo REALE, é o tempo da duração ${ }^{8}$, que não é fugidio, relâmpago como um coup de foudre, mas sim aquele que perdura na recíproca atração, em incessante doação e conquista, em participação perene.

Sabiamente constata que há, também,

${ }^{2}$ Variaçōes, cit. p. 39.

3 Variaçôes, cit. p. 158.
4 Variaçōes, cit. p. 106.

Revista da Faculdade de Direito da UFRGS, v. 19, Março/2001

Revista da Faculdade de Direito da UFRGS, v. 19, Março/2001 
um tempo do velho ${ }^{9}$, no qual se contabilizam os momentos positivos adquiridos e os negativos perdidos, mas sem encerrar o balanço, para ao contrário, tomar as gratas recordações como patamar do qual vislumbra o futuro, para sabe o que ainda pode esperar, pois enquanto se espera não se pode sentir a velhice com resmungos e amarguras".

É esta, sem dúvida, a melhor receita para se alcançar os noventa anos atento à vida, do futebol à globalização, fazendo de cada artigo de jornal a primeira colaboração na imprensa à espera de um novo reconhecimento, que nem os títulos honoris causa tornam dispensável. É o tempo do velho que remoça na esperança.

Lição importante surge na análise de como é o tempo vivido por nós brasileiros, sem a paciência própria dos que sabem que a natureza não anda aos saltos, pois o bom senso natural mostra que se deve passar gradativamente "da semente à flor e da flor para o fruto, com a sabedoria de saboreá-lo maduro"10 , lembrando que já SAINT HILAIRE anotava que, no Brasil, comem-se os frutos verdes, não esperando que amadureçam.

O brasileiro busca sempre alcançar seus objetivos de forma apressada, confiando na improvisação, certo de que com facilidade obterá os resultados pretendidos sem o esforço contínuo, razão por que REALE decifra dois complexos nacionais que devem ser superados: o estalo de Vieira e o jeitinholl. O estalo de Vieira entendido como ciência súbita e gratúta, e o jeitinho como capacidade inata de supera dificuldades. Devemos vencer estas formas de

vida viciadas, ainda mais diante do avanço tecnológico que instaura a imediatidade, acelerando o desejo de obtenção repentina de resultados. Cumpre, assim, "dar valor ao que se aperfeiçoa no tempo".

Mas, questão fundamental está em indagar se o tempo se finda com a morte, se com a morte se cai na escuridão e no nada. A idade fez deste agnóstico um espírito imbuído de religiosidade, chegando à conclusão de que "somos uma ilha de problemas cercada pelo oceano de mistérios ${ }^{12}$ ".

REALE enfrenta o desafio de decifrar em que consiste o ato de orar, que a seu ver decorre de uma "necessidade de crer, de crer sem vacilação" ${ }^{13}$, pregando por proteção nesta e na vida depois da morte. Assim, os homens, perante o transcendente, fazem-se mais próximos e mais iguais, ao'compartilharem todos a mesma crença, estabelecendo-se uma comunhão, pois o ato de orar é concomitantemente um isolamento e uma partici pação.

Por isso, a seu ver a experiência religiosa constitui um ato de doação ${ }^{14}$, uma entrega espontânea e confiante a algo superior, dominante e envolvente de quem crê, uma vivência do absoluto nos quadrantes da finitude humana.

A meu ver, não poderia o pensador que elege a pessoa humana como valor-fonte de todos os valores, dela defluindo os valores da liberdade espiritual e da justiça, não crer em um significado após a morte. O reconhecimento da dignidade da pessoa humana não se com- padece com a visão da morte como o nada ou a escuridão. Por isso, diz REALE, "proclamada a inexistência de Deus, tudo o que existe, nem o homem, nem a infinidade do universo teria sentido......Não haveria também razão para o dever moral que é só próprio da espécie huma$\mathrm{na}^{15} "$

Mais intenso se faz o sentimento religioso diante da morte da mulher amada, e dois meses após seu falecimento escreve ${ }^{16}:$ "creio que a alma se desprende do corpo e passa para outra forma de existir, isenta de materialidade e, como tal, mais pura"..... "Sobrevem a fé pelas vias do amor".

Transita na lembrança dos momentos mais infimos, passados juntos, aprendendo a viver com lágrimas nos olhos, sabendo que sentir saudade da pessoa amada "é uma forma de ressuscitá-la", fazendo-a presente.

A perda irreparável do ente amado o reconcilia com a morte, deixando de a temer, pois é o caminho para restabelecer a ligação com o ser querido que partiu. Mas não perdura estático e indiferente ao mundo e aos que lhe são próximos, à espera da morte. Sente, então, "a necessidade imperiosa de amar, de maneira diversa e mais profunda filhos, netos e bisnetos".

REALE demonstra, portanto, com sua vida, seus sofrimentos, vitórias e constantes esperanças, a teoria de que o homem é enquanto deve ser, cumprindo a máxima que formulara na juventude, em 1933, propondo-se a "teorizar a vida e viver a teoria na unidade indissolúvel do pensamento e da ação". Sempre foi enquanto devia ser, e hoje aos noventa é enquanto deve ser. Vive porque tem esperança.

Fez e faz da vida um perene projeto de realização plena do espírito, que não esmorece diante dos obstáculos que a existência lhe apresenta. $\mathrm{E}$ assim viverá ainda por muitos anos. $\mathrm{E}$ essa a minha esperança.

${ }^{9}$ Variaçôes, cit. p. 43.

${ }^{10}$ Variaçōes, cit. p. 133.

"Variaçôes, cit. p. 140.

12 Variaçóes, cit. ,p. 100.

${ }^{13}$ Variações, cit., p. 97

${ }^{14}$ Variações,cit., p70. 